\title{
Karakteristik Roti Bebas Gluten Berbahan Dasar Pati Ganyong Termodifikasi
}

\author{
Characteristics of Gluten Free Bread from Modified Canna Starch \\ P. Parwiyanti ${ }^{1 *}$, Filli Pratama ${ }^{1}$, Agus Wijaya ${ }^{1}$, Nura Malahayati ${ }^{1}$ \\ Jurusan Teknologi Pertanian, Fakultas Pertanian, Universitas Sriwijaya, \\ Jl. Palembang-Prabumulih Km. 32, Indralaya, Ogan Ilir, Sumatera Selatan 30662, Indonesia \\ Email: parwiyanti_ibu@yahoo.com
}

Tanggal submisi: 3 Desember 2016; Tanggal penerimaan: 31 Agustus 2018

\begin{abstract}
ABSTRAK
Pati ganyong termodifikasi Heat Moisture Treatment (HMT) dengan penambahan gum xanthan (GX) berpotensi digunakan sebagai bahan dasar roti bebas gluten. Penelitian ini bertujuan mengetahui karakteristik fisik dan sensoris roti bebas gluten dari beberapa jenis pati ganyong termodifikasi. Beberapa jenis pati ganyong termodifikasi pada formulasi adonan roti digunakan sebagai bahan utama penelitian. Penelitian menggunakan Rancangan Acak Lengkap dengan satu faktor perlakuan yaitu jenis pati (pati ganyong termodifikasi HMT-GX, pati ganyong termodifikasi HMT, pati ganyong alami yang ditambah gum xanthan 1,5\%, pati ganyong alami, pati jagung, dan tepung terigu). Karakteristik roti yang diamati meliputi volume spesifik, warna, tekstur, rasio tinggi dan diameter roti, serta sensoris. Hasil penelitian menunjukkan bahwa perlakuan terbaik berdasarkan karakteristik fisik dan sensoris dihasilkan dengan menggunakan bahan dasar pati ganyong termodifikasi HMT-GX. Karakteristik roti bebas gluten yang dihasilkan memiliki volume spesifik $2,85 \pm 0,017 \mathrm{~cm}^{3} / \mathrm{g}$, warna $\left(L^{*}, a^{*}, b^{*}\right.$ berturut-turut 75,13; $+9,370 ;+29,40)$, tekstur $109,03 \pm 7,50 \mathrm{~g}_{\mathrm{f}}$ rasio tinggi dan diameter roti 0,74, skor hedonik untuk rasa, warna, tekstur dan aroma berturut-turut 5,34; 5,46; 5,56, dan 5,80 (range nilai hedonik dari $1=$ sangat tidak suka sampai dengan 7 = sangat suka).
\end{abstract}

Kata kunci: Pati ganyong termodifikasi; heat moisture treatment; roti bebas gluten; gum xanthan

\section{ABSTRACT}

Modified canna starch by Heat Moisture Treatment (HMT) and xanthan gum (GX) showed had potential used in the formulation of gluten-free breads. This study aimed to explore the phyiscals and sensory characteristics of glutenfree breads from some types of modified canna starch. The main material was some types of modified canna starch. The study was applied Completely Randomized Design with one treatment factor of starches type (HMT-GX and HMT modified canna starches, natural canna starch with and without $1.5 \%$ of xanthan gum addition, corn starch, and wheat flour). While the characteristics of bread determined include: specific volume, color, texture, ratio between height and diameter of bread, and sensory. The results showed that the best treatment based on physical and sensory characteristics was produced using HMT-GX modified canna starch. The characteristics of gluten free bread produced have a specific volume of $2.85 \pm 0.017 \mathrm{~cm}^{3} / \mathrm{g}$, color $(L *, a *, b * 75.13,+9.370$; +29.40 , respectively), texture of $109.03 \pm 7.50 \mathrm{~g}_{f}$, bread high and diameter ratio of 0.74 , hedonic score for taste, color, texture and aroma respectively 5.34; 5.46; 5.56, and 5.80 repectively (range of hedonic values from $1=$ very dislike to $7=$ very like).

Keywords: Canna edulis bread; heat moisture treatment; modified starch; xanthan gum 


\section{PENDAHULUAN}

Ganyong (Canna edulis Kerr.) merupakan salah satu jenis umbi-umbian yang potensial dikembangkan di Indonesia. Bagian tanaman ganyong yang dapat dimanfaatkan sebagai bahan pangan adalah umbinya. Umbi ganyong dapat diolah menjadi tepung dan pati yang selanjutnya digunakan sebagai bahan baku atau bahan tambahan pada industri pangan (Widjajaputra, 2007; Slamet, 2010). Pati ganyong tidak mengadung gluten sehingga dapat dikonsumsi oleh anak berkebutuhan khusus, seperti autis dan penderita celiac. Pati ganyong mempunyai karakteristik mudah teretrogradasi, struktur kristalin tipe B, berkadar amilosa tinggi, viskositas tinggi, dan membentuk gel (Watcharatewinkul dkk., 2009). Sifat pati ganyong yang mudah teretrogradasi dan memiliki viskositas tinggi membatasi penggunaan pati ganyong pada industri pengolahan pangan. Pangan berbahan pati ganyong mudah mengeras pada suhu ruang sehingga pati ganyong lebih banyak digunakan sebagai bahan pembentuk gel. Untuk memperluas penggunaan pati ganyong dalam industri pangan, khususnya produk roti perlu dilakukan modifikasi.

Pati termodifikasi Heat Moisture Treatment (HMT) berpotensi untukdibuatmenjadi produkroti. Berdasarkan hasil penelitian Onyango dkk. (2013), tekstur roti bebas gluten berbahan tapioka HMT lebih lembut dibandingkan dengan roti yang dibuat menggunakan tapioka alami. Kelemahan pati termodifikasi HMT pada produk roti adalah roti yang dihasilkan tidak mengembang karena struktur gelnya tidak kuat dan mudah mengempes (collapse). Untuk meningkatkan daya mengembang, perlu ditambahkan bread improver selama pengolahan roti berbahan dasar pati dan tepung selain terigu. Salah satu bahan tambahan pangan yang dapat berfungsi sebagai bread improver terutama bahan pengembang pada roti non terigu adalah gum xanthan (GX) (Gambus dkk., 2007; Turabi dkk., 2010; Peressini dkk., 2011; Palaniraj dan Jayaraman, 2011). GX dapat berfungsi sebagai pengganti gluten pada produk roti non terigu. Weber dkk. (2009) menjelaskan bahwa GX merupakan hidrokoloid yang dapat menurunkan mobilitas fraksi air dan mempengaruhi pengaturan kembali amilosa dan amilopektin granula pati sehingga dapat memperkuat matrik gel pati yang diperlukan dalam proses pengembangan adonan roti non terigu selama pemanggangan.

Sebagaimana dilaporkan oleh Parwiyanti dkk. (2015), modifikasi pati ganyong dengan HMT pada suhu $80{ }^{\circ} \mathrm{C}$, waktu 8 jam, kadar air pati $15 \%$ dan konsentrasi gum xanthan $1 \%$ (modifikasi HMT-GX) dapat menghasilkan pati ganyong yang sifat fisiknya mendekati tepung terigu berkadar protein sedang. Sifat fisik pati ganyong termodifikasi HMT-GX tersebut adalah swelling power (SP) $16,90 \pm 0,48 \mathrm{~g} / \mathrm{g}$, indeks kelarutan dalam air (IKA) 10,28 $\pm 0,25 \%$, indeks absobsi air (IAA) $112,58 \pm 0,38 \%$, derajat pengembangan (DP) $0,94 \pm 0,11 \mathrm{~mL} / \mathrm{g}$, dan densitas kamba (DK) 0,73 \pm $0,026 \mathrm{~g} / \mathrm{mL}$ serta tidak merubah morfologi granula pati ganyong (Parwiyanti dkk., 2015). Pati ganyong termodifikasi HMT-GX berpotensi digunakan sebagai bahan dasar roti bebas gluten karena sifat fisiknya mendekati tepung terigu berkadar protein sedang. Roti merupakan makanan yang telah menjadi menu sarapan bagi kebanyakan orang Indonesia karena praktis, tidak memerlukan persiapan yang lama, dan dapat memenuhi kebutuhan energi, terutama kelompok penderita celiac dan autis. Penelitian ini bertujuan mendapatkan data karakteristik fisik dan sensoris roti bebas gluten dari beberapa jenis pati ganyong termodifikasi.

\section{METODE PENELITIAN}

\section{Bahan dan Alat}

Bahan yang digunakan meliputi pati ganyong dari pengolahan pati ganyong di desa Sendang Sari, kabupaten Kulon Progo, Yogyakarya, gum xanthan (GX) FG 80 mesh (PT. Brataco), telur, gula, susu full cream, instant dry yeast (Vita), margarin (blue band), pati jagung, dan tepung terigu protein sedang (segitiga biru). Sedangkan alat yang digunakan adalah LFRA Texture Analyzer, Color Checker Konica Minolta CR-1 Jepang, neraca analitik (Ohaus), oven (Memmert), peralatan uji hedonik, dan peralatan gelas.

\section{Rancangan Percobaan dan Analisa Data}

Penelitian disusun menggunakan Rancangan Acak Lengkap dengan satu faktor perlakuan yaitu jenis pati atau tepung. Perlakuan tersebut adalah pati ganyong termodifikasi HMT-GX (suhu $80{ }^{\circ} \mathrm{C}$, waktu 8 jam, kadar air pati $15 \%$, konsentrasi gum xanthan $1,5 \%$ ), pati ganyong termodifikasi HMT (suhu $80^{\circ} \mathrm{C}$, waktu 8 jam, kadar air pati $15 \%$ ), pati ganyong alami yang ditambah gum xanthan $1,5 \%$, pati ganyong alami, pati jagung, dan tepung terigu. Ulangan 3 kali. Data dari setiap parameter dianalisis dengan sidik ragam (ANOVA) pada $a=5 \%$, perlakuan yang berpengaruh nyata diuji dengan uji BNJ $(a=5 \%)$. Data hasil uji hedonik dianalisa dengan metode Friedman Conover.

\section{Modifikasi Pati Ganyong dengan HMT dan Gum Xanthan (GX)}

Proses modifikasi pati ganyong mengacu pada proses Onyango dkk. (2013) dengan modifikasi. Penetapan kadar air pati ganyong $15 \%$ dilakukan 
dengan cara menganalisa kadar air pati ganyong awal yang dilanjutkan dengan penambahan akuades sampai kadar air mencapai $15 \%$ (b/b). Jumlah akuades yang ditambahkan dihitung menggunakan rumus kesetimbangan massa seperti Persamaan 1. Jumlah air yang ditambahkan pada pati ganyong adalah selisih berat pati ganyong awal dengan pati ganyong berkadar air $15 \%$. Pati ganyong berkadar air $15 \%$ dimasukkan dalam Erlenmeyer bertutup dan disimpan pada suhu 4 ${ }^{\circ} \mathrm{C}$ selama 12 jam untuk mencapai kesetimbangan. Pati ganyong berkadar air $15 \%$ dipanaskan dalam oven pada suhu $80^{\circ} \mathrm{C}$ selama 8 jam. Pati ganyong termodifikasi dikeringkan dalam oven pada suhu $45^{\circ} \mathrm{C}$ sampai kadar air sekitar $10 \%$, disimpan dalam kemasan plastik poli propilen (pp) pada suhu ruang untuk dianalisa. Modifikasi HMT-GX dilakukan dengan cara yang sama dengan modifikasi HMT tetapi ditambahkan GX 1,5\% pada pati ganyong berkadar air $15 \%$ sebelum dilakukan pemanasan.

$$
A=(100 \%-K A) \cdot M 1
$$

A adalah jumlah akuades yang ditambahkan ( $\mathrm{ml})$, KA kadar air pati ganyong awal (\%), M1 adalah berat pati ganyong awal $(\mathrm{g})$ yang berkadar air $15 \%$.

\section{Formulasi Bahan pada Pembuatan Roti}

Formulasi bahan dan metode pembuatan roti bebas gluten berdasarkan formulasi bahan dan metode pembuatan roti dalam penelitian Al-Dmoor (2014), Gambus (2007), dan Rakkar (2007) yang dimodifikasi melalui penelitian pendahuluan. Formulasi bahan untuk membuat roti bebas gluten disajikan pada Tabel 1 .

Proses pembuatan rotinya terdiri atas pencampuran semua bahan sesuai dengan formulasi bahan (Tabel 1), pembentukan adonan menjadi bulatan kecil dengan berat $10 \mathrm{~g} /$ bulatan, bulatan adonan dimasukkan ke dalam loyang yang telah diolesi margarin dan ditaburi pati ganyong, didiamkan (proofing) pada suhu ruang $\left(32 \pm 2^{\circ} \mathrm{C}\right.$ ) selama 30 menit, pemanggangan pada

Tabel 1. Formulasi bahan untuk membuat roti

\begin{tabular}{ll}
\hline Jenis bahan & Jumlah bahan \\
\hline Pati atau tepung & $230 \mathrm{~g}$ \\
Putih telur & $25 \mathrm{~mL}$ \\
Kuning telur & $30 \mathrm{~mL}$ \\
Margarin & $30 \mathrm{~g}$ \\
Gula & $50 \mathrm{~g}$ \\
Susu full cream cair & $100 \mathrm{~mL}$ \\
Instant dry yeast & $5 \mathrm{~g}$ \\
\hline
\end{tabular}

suhu $180{ }^{\circ} \mathrm{C}$ selama 30 menit, pendinginan 2 jam, penyimpanan dalam stoples untuk dianalisa.

Parameter yang diamati meliputi volume spesifik (VS) (Putri dkk., 2014), warna (Colour Checker Konica Minolta CR-1 Jepang), kerenyahan (LRFA Texture Analyzer dengan pengaturan: distance $5,0 \mathrm{~mm}$, speed $5 \mathrm{~mm} / \mathrm{s}$, menggunakan probe TA 43) (Alvarenga dkk., 2011), rasio tinggi/diameter (micrometer skrup), struktur pori roti diamati dengan mikroskop perbesaran 200x dan uji hedonik (Pratama, 2012).

\section{HASIL DAN PEMBAHASAN}

\section{Volume Spesifik Roti}

Volume spesifik (VS) merupakan volume per satuan berat roti yang mencerminkan derajat pengembangannya. Pada roti diharapkan mempunyai nilai VS yang besar. Nilai VS roti berkisar antara 2,36 sampai $3,11 \mathrm{~cm}^{3} \mathrm{~g}^{-1}$. Nilai VS tertinggi $\left(3,11 \mathrm{~cm}^{3} \mathrm{~g}\right.$ $\left.{ }^{1}\right)$ dihasilkan pada roti yang dibuat dari pati jagung, sedangkan VS terendah $\left(2,36 \mathrm{~cm}^{3} \mathrm{~g}^{-1}\right)$ terdapat pada roti yang dibuat dari pati ganyong. Hasil analisis keragaman menunjukkan bahwa perlakuan jenis pati berpengaruh nyata $(p<5 \%)$ terhadap VS roti. Hasil uji BNJ $(a=$ $5 \%$ ) pengaruh perlakuan jenis pati terhadap VS dapat dilihat pada Tabel 2 .

Tabel 2 menunjukkan bahwa perlakuan jenis pati ganyong termodifikasi HMT-GX berbeda tidak nyata dengan pati ganyong-GX tetapi berbeda nyata dengan perlakuan jenis pati lainnya terhadap VS roti.

Pati ganyong termodifikasi HMT, HMT-GX dan pati ganyong yang ditambah GX menghasilkan roti dengan VS yang lebih tinggi dibandingkan pati ganyong alami. Sedangkan roti berbahan dasar pati jagung dan pati ganyong HMT walaupun VS lebih besar namun rotinya tipis dan mudah hancur. Hal ini didukung dengan data rasio tinggi dan diameter roti yang nilai lebih rendah dibandingkan roti berbahan dasar pati ganyong termodifikasi HMT-GX (Tabel 5) dan bentuk

Tabel 2. Hasil uji BNJ pengaruh jenis pati terhadap volume spesifik (VS) roti

\begin{tabular}{ll}
\hline Jenis pati/tepung & Volume spesifik (VS) $\left(\mathrm{cm}^{3} / \mathrm{g}\right)$ \\
\hline Pati ganyong HMT-GX & $2,85 \pm 0,017^{\mathrm{c}}$ \\
Pati ganyong HMT & $3,07 \pm 0,132^{\mathrm{d}}$ \\
Pati ganyong-GX & $2,79 \pm 0,018^{\mathrm{c}}$ \\
Pati ganyong & $2,36 \pm 0,008^{\mathrm{a}}$ \\
Pati jagung & $3,11 \pm 0,015^{\mathrm{d}}$ \\
Tepung terigu & $2,63 \pm 0,015^{\mathrm{b}}$ \\
\hline
\end{tabular}

Keterangan: Angka yang diikuti huruf yang sama pada kolom yang sama berarti berbeda tidak nyata pada uji BNJ 5\%. BNJ 5\% =0,15 
roti serta penampang melintang rotinya (Gambar 1b). Hasil penelitian ini didukung pernyataan Weber dkk. (2009) bahwa energi yang diserap granula pati selama pemanasan dapat membuka lipatan heliks ganda amilopektin pati dan memfasilitasi pengaturan atau pembentukan ikatan-ikatan baru antar molekul sehingga membentuk struktur roti yang berongga.

VS roti yang dibuat dari pati ganyong dengan penambahan GX $1,5 \%$ dan modifikasi HMT telah menunjukkan peningkatan. Karena adanya pertambahan viskositas pati ganyong sesuai dengan hasil penelitian Parwiyanti dkk. (2016) yang mampu menahan retensi gas selama proofing. Parwiyanti dkk. (2016) menyatakan bahwa nilai derajat pengembangan pati ganyong termodifikasi HMT-GX lebih tinggi dibandingkan pati ganyong alami. Hal ini mencerminkan kemampuan adonan pati menahan peruraian gas akibat pemanggangan. GX kemungkinan berikatan dengan amilosa dan amilopektin sehingga pada saat dilakukan pemanasan HMT mempengaruhi kemampuan pati dalam pembentukan matriks adonan pada proses pemangganan. VS roti yang besar disebabkan oleh GX dapat menurunkan mobilitas fraksi air dalam sistem dan mengurangi hidrasi bagian amorphous granula pati (Weber dkk., 2009). Hal ini dapat mempengaruhi ikatan hidrogen inter dan intra molekul amilosa dan amilopektin dalam granula pati sehingga dapat menggangu keteraturan struktur granula pati. Ikatan hidrogen merupakan ikatan kimia yang lemah. Kondisi ini memberi peluang air untuk mengimbibisi granula pati sehingga dapat meningkatkan swelling power. Peningkatan swelling power pati ganyong menyebabkan tingginya VS roti yang dihasilkan. Syamsir dkk. (2012) menjelaskan bahwa energi yang diserap granula pati selama pemanasan akan membuka lipatan heliks ganda amilopektin dan memfasilitasi pengaturan atau pembentukan ikatan-ikatan baru antarmolekul. Proses restruksisasi amilosa pada daerah amorphous selama HMT menyebabkan molekul inter- dan antar ikatan hidrogen lebih renggang, sehingga molekul air mudah masuk ke dalam granula pati.

\section{Warna Roti}

Intensitas warna roti diukur menggunakan Colour Checker. Nilai $L^{*}$ mengukur lightness, dan 2 koordinat $a^{*}$ dan $b^{*}$. $L^{*}$ menyatakan parameter kecerahan. Notasi $a^{*}$ menunjukkan warna kromatik campuran merah hijau dan nilai a $(+)$ berkisar antara 0 sampai +100 untuk warna merah dan nilai a(-) berkisar antara 0 sampai -80 untuk warna hijau. Notasi $b^{*}$ menunjukkan warna kromatik campuran biru-kuning dan nilai $b(+)$ berkisar 0 sampai +70 untuk warna kuning dan nilai $b(-)$ berkisar 0 sampai -70 untuk warna biru. Nilai $L^{*}$ roti berkisar antara 71,73 sampai 77,87 , dengan kisaran nilai $a^{*}$ dan $b^{*}$ berturut-turut $+7,73$ sampai $+12,50$ dan $+24,57$ sampai $+35,33$. Nilai $a^{*}$ dan $b^{*}$ roti positif yang menunjukkan kecenderungan warna merah dan kuning. Hasil analisis keragaman menunjukkan bahwa perlakuan jenis pati berpengaruh nyata $(p<5 \%)$ terhadap nilai warna roti $\left(L^{*}, a^{*}\right.$ dan $\left.b^{*}\right)$. Hasil uji BNJ $(a=5 \%)$ pengaruh perlakuan jenis pati terhadap warna dapat dilihat pada Tabel 3.

Tabel 3 menunjukan bahwa perlakuan jenis pati ganyong HMT berbeda nyata dengan jenis pati yang lainnya terhadap nilai $L^{*}$. Perlakuan jenis pati ganyong HMT berbeda tidak nyata dengan pati jagung, pati ganyong, pati ganyong HMT-GX, tetapi terbeda nyata dengan pati ganyong-GX dan tepung terigu terhadap nilai $a^{*}$. Perlakuan tepung terigu berbeda nyata dengan jenis pati yang lainnya terhadap nilai $b^{*}$. Perbedaan warna roti, nilai $L^{*}$ disebabkan oleh kecerahan jenis pati ganyong HMT yang lebih gelap dibandingkan jenis pati yang lain. Derajat putih pati ganyong menurut Utomo dkk. (2012) 55,2\%. Warna roti berbahan pati ganyong HMT-GX yang lebih rendah dibandingkan roti berbahan dasar pati jagung disebabkan oleh perbedaan warna bahan bakunya yang berwarna putih kecoklatan.

\section{Tekstur Roti}

Tekstur roti diamati dengan mengukur energi yang diperlukan untuk menekan roti yang mencerminkan kerenyahan roti. Semakin tinggi nilai tekstur mencerminkan tekstur roti yang semakin keras. Hasil

Tabel 3. Hasil uji BNJ pengaruh jenis pati terhadap warna $\left(L^{*}, a^{*}, b^{*}\right)$ roti

\begin{tabular}{llll}
\hline Jenis pati/tepung & $L^{*}$ & $a^{*}$ & $b^{*}$ \\
\hline Pati ganyong HMT-GX & $75,13 \pm 0,25^{\mathrm{b}}$ & $+9,37 \pm 1,14^{\mathrm{ab}}$ & $+29,40 \pm 2,15^{\mathrm{b}}$ \\
Pati ganyong HMT & $77,87 \pm 0,60^{\mathrm{c}}$ & $+7,97 \pm 0,11^{\mathrm{a}}$ & $+24,57 \pm 0,90^{\mathrm{a}}$ \\
Pati ganyong-GX & $73,03 \pm 0,60^{\mathrm{a}}$ & $+12,50 \pm 0,50^{\mathrm{b}}$ & $+31,00 \pm 0,79^{\mathrm{b}}$ \\
Pati ganyong & $76,33 \pm 0,29^{\mathrm{b}}$ & $+9,00 \pm 0,26^{\mathrm{ab}}$ & $+27,33 \pm 1,04^{\mathrm{ab}}$ \\
Pati jagung & $76,50 \pm 0,10^{\mathrm{b}}$ & $+7,73 \pm 0,50^{\mathrm{a}}$ & $+31,57 \pm 0,67^{\mathrm{b}}$ \\
Tepung terigu & $71,73 \pm 1,00^{\mathrm{a}}$ & $+10,17 \pm 1,06^{\mathrm{b}}$ & $+35,33 \pm 0,71^{\mathrm{c}}$ \\
\hline
\end{tabular}

Keterangan: Angka yang diikuti huruf yang sama pada kolom yang sama berarti 
Tabel 4. Hasil uji BNJ pengaruh jenis pati terhadap tekstur roti

\begin{tabular}{ll}
\hline Jenis pati/tepung & Tekstur $\left(\mathrm{g}_{\mathrm{f}}\right)$ \\
\hline Pati ganyong HMT-GX & $109,03 \pm 7,50^{\mathrm{ab}}$ \\
Pati ganyong HMT & $108,30 \pm 0,10^{\mathrm{ab}}$ \\
Pati ganyong-GX & $150,27 \pm 7,50^{\mathrm{c}}$ \\
Pati ganyong & $103,53 \pm 2,58^{\mathrm{a}}$ \\
Pati jagung & $146,43 \pm 3,85^{\mathrm{c}}$ \\
Tepung terigu & $120,77 \pm 5,75^{\mathrm{b}}$ \\
\hline
\end{tabular}

Keterangan: Angka yang diikuti huruf yang sama pada kolom yang sama berarti berbeda tidak nyata pada uji BNJ 5\%. BNJ 5\% tekstur $=14,48$

analisis keragaman menunjukkan bahwa perlakuan jenis pati berpengaruh nyata $(p<5 \%)$ terhadap tekstur roti. Hasil uji BNJ ( $a=5 \%$ ) pengaruh perlakuan jenis pati terhadap tekstur roti dapat dilihat pada Tabel 4 . Tabel 4 menunjukkan bahwa perlakuan pati ganyong HMT-GX berbeda tidak nyata dengan perlakuan jenis pati ganyong HMT dan pati ganyong, tetapi berbeda nyata dengan jenis pati lainnya.

Nilai tekstur roti berkisar antara 103,53 sampai $150,27 \mathrm{~g}_{\mathrm{f}}$. Nilai tekstur tertinggi $\left(150,27 \pm 7,50 \mathrm{~g}_{\mathrm{f}}\right)$ dihasilkan pada roti yang dibuat dari pati ganyong yang ditambah 1,5\% GX, sedangkan tekstur terendah (103,53 $\mathrm{g}_{\mathrm{f}}$ ) terdapat pada roti yang dibuat dari pati ganyong. Roti yang dibuat dari pati ganyong termodifikasi HMT dan HMT-GX mempunyai tekstur yang rapuh (keras tetapi mudah pecah) seperti halnya roti yang dibuat dari pati ganyong. Hal ini disebabkan pati ganyong tergolong pati berkadar amilosa tinggi $(42,40 \% \mathrm{db})$ (Harmayani dkk., 2011). Keunggulan roti ganyong termodifikasi HMT-GX dibandingkan roti yang dibuat dari pati ganyong yang lainnya adalah rotinya kompak tetapi renyah. Kekompakan tersebut disebabkan oleh penambahan gum xanthan selama modifikasi HMT. Gum xanthan merupakan salah satu jenis senyawa polimer yang mampu meniru sifat viskoelastis gluten (Hager dan Arendt, 2013; Peressini dkk., 2011), sehingga dapat menjadi produk roti lebih kompak.

\section{Rasio Tinggi dan Diameter Roti}

Rasio Tinggi dan diameter roti mencerminkan ketebalan roti. Hasil analisis keragaman menunjukkan bahwa perlakuan jenis pati berpengaruh nyata $(p<$ $5 \%)$ terhadap rasio tinggi dan diameter roti. Hasil uji BNJ $(a=5 \%)$ pengaruh perlakuan jenis pati terhadap rasio tinggi dan diameter roti dapat dilihat pada Tabel 5. Tabel 5 menunjukkan bahwa perlakuan pati ganyong HMT-GX berbeda tidak nyata dengan perlakuan pati ganyong-GX, tetapi berbeda nyata dengan jenis pati lainnya.
Tabel 5. Hasil uji BNJ pengaruh jenis pati terhadap rasio tinggi dan diameter roti

\begin{tabular}{ll}
\hline Jenis pati/tepung & $\begin{array}{l}\text { Rasio tinggi dan diameter } \\
\text { roti }(\mathrm{mm} / \mathrm{mm})\end{array}$ \\
\hline Pati ganyong HMT-GX & $0,74 \pm 0,043^{\mathrm{d}}$ \\
Pati ganyong HMT & $0,24 \pm 0,001^{\mathrm{b}}$ \\
Pati ganyong-GX & $0,75 \pm 0,010^{\mathrm{d}}$ \\
Pati ganyong & $0,18 \pm 0,013^{\mathrm{a}}$ \\
Pati jagung & $0,14 \pm 0,005^{\mathrm{a}}$ \\
Tepung terigu & $0,59 \pm 0,018^{\mathrm{c}}$ \\
\hline
\end{tabular}

Keterangan: Angka yang diikuti huruf yang sama pada kolom yang sama berarti berbeda tidak nyata pada uji BNJ 5\%. BNJ 5\% rasio tinggi/diameter roti $=0,06$

Nilai rasio tinggi dan diameter roti berkisar antara 0,14 sampai 0,75 . Nilai rasio tinggi dan diameter tertinggi $(0,75)$ dihasilkan pada roti yang dibuat dari pati ganyong yang ditambah $1,5 \% \mathrm{GX}$, sedangkan rasio tinggi dan diameter roti terendah $(0,14)$ terdapat pada roti yang dibuat dari pati jagung. Penambahan GX dapat meningkatkan nilai rasio tinggi dan diameter roti disebabkan karena GX merupakan hidrokoloid yang mampu mengikat air dalam jumlah besar sehingga adonan roti lebih kompak. Gum xanthan digunakan sebagai gelling agent (Gomashe dkk., 2013). Sejalan dengan hasil penelitian Gambus dkk. (2007) bahwa roti berbahan baku komposit pati kentang, pati jagung dan tepung jagung yang diberi bread improver campuran gum xanthan, guar gum, dan pektin dengan proposi yang sama menghasilkan volume roti yang lebih besar dibandingkan bila hanya menggunakan campuran guar gum dan pektin.

\section{Struktur Pori Roti}

Bentuk, penampang melintang, penampang membujur, dan struktur pori roti dapat dilihat pada Gambar 1.

Berdasarkan penampang membujur roti (Gambar 1 a, b), dapat menjelaskan peran gum xanthan, roti yang dibuat dari pati tanpa penambahan gum xanthan menghasilkan roti tipis yang mudah hancur. Vamadevan dan Bertoft (2014) menjelaskan bahwa kemampuan mengembang pati berhubungan dengan integritas struktural pati yang dipengaruhi oleh interaksi amilosa-amilosa, amilosa-amilopektin, dan amilopektinamilopektin di daerah kristalin dan amorphous (Gambar 1a).

Struktur pori-pori roti (Gambar 1b) yang dihasilkan dari pati ganyong termodifikasi HMT-GX sudah menyerupai roti yang dibuat dari tepung terigu, poripori banyak dan hampir sama ukurannya. Sedangkan roti yang dibuat dari pati ganyong tanpa penambahan 

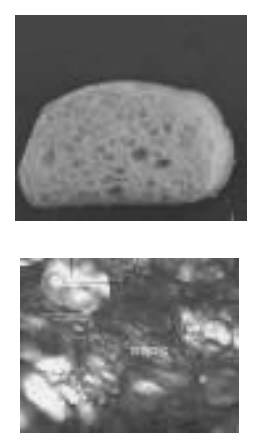

Roti terigu
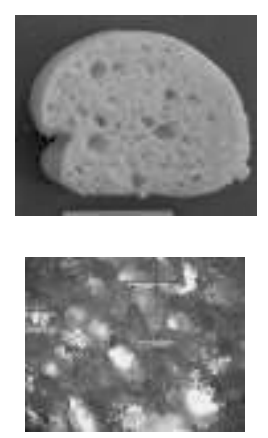

Roti pati ganyong yang ditambah GX
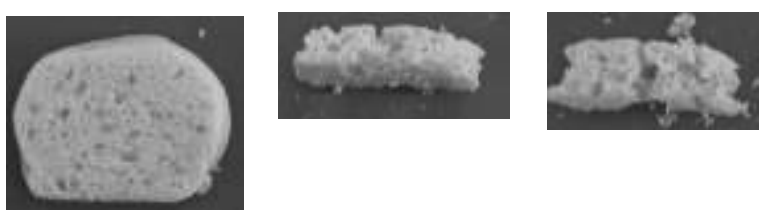

(a)
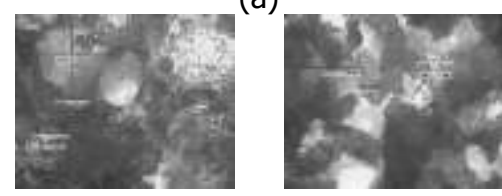

(b)

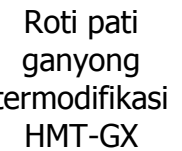

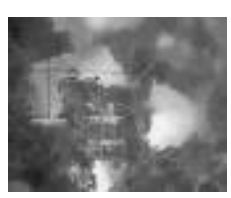

Roti pati ganyong termodifikasi HMT
Roti pati

Ganyong
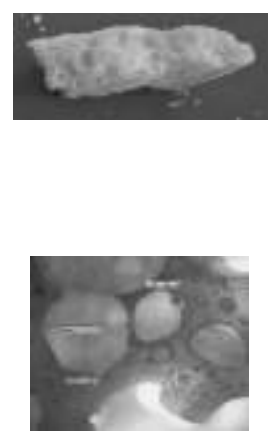

Roti pati jagung

Gambar 1. Penampang roti (a), dan struktur pori-pori roti pada pengamatan dengan mikroskop perbesaran 200x (b)

gum xanthan mempunyai struktur pori-pori yang sangat rapat dengan rongga udara besar tidak seragam. Sifat GX mampu mengabsorpsi air cukup besar (Kohajdova dan Karovicova, 2008). Tersedianya air yang lebih banyak selama pemanasan menyebabkan porositas matrik gel pati lebih besar dan banyak. Vamadevan dan Bertoft (2014) menjelaskan bahwa kemampuan mengembang pati berhubungan dengan integritas struktural pati terdiri dari amilosa dan amilopektin yang membentuk matrik granula pati pada saat proses gelatinisasi. Penelitian Parwiyanti dkk. (2015) menghasilkan bahwa interaksi waktu HMT dan konsentrasi gum xanthan menyebabkan terjadinya perubahan nyata terhadap swelling power dan indeks kelarutan dalam air pada pati ganyong. Pati ganyong yang dimodifikasi menggunakan HMT 8 jam dan konsentrasi gum xanthan $1 \%$ menunjukkan perubahan swelling power yang lebih tinggi dari pati ganyong alami dan tepung terigu dan mempunyai indeks kelarutan dalam air mendekati tepung terigu, sehingga dapat dikembangkan lebih lanjut untuk substitusi terigu pada produk rerotian.

\section{Analisis Sensoris Roti Ganyong}

Analisis sensoris dilakukan untuk mengetahui tingkat penerimaan konsumen terhadap roti yang dibuat dari pati ganyong termodifikasi HMT-GX dibandingkan dengan roti yang dibuat dari pati jagung dan tepung terigu sebagai produk kontrol. Karakteristik sensoris roti diamati menggunakan uji hedonik yang dilakukan oleh 50 panelis dengan rentang skor 1 - 7 (sangat tidak suka sampai sangat suka) dan aspek yang diuji: rasa, warna, tekstur dan aroma. Hasil uji hedonik ditampilkan pada Tabel 6. Kesukaan panelis terhadap parameter rasa, warna, tekstur dan aroma berturut- turut berkisar pada nilai 2,84 sampai 5,$34 ; 2,88$ sampai 5,$36 ; 2,3$ sampai 5,10 ; dan 3,78 sampai 5,8 (sedikit tidak suka sampai suka).

Analisis Friedman Conover menunjukkan adanya perbedaan kesukaan terhadap rasa, warna, tekstur, dan aroma pada keenam jenis bahan roti $(p<5 \%)$. Hasil uji lanjut menyatakan bahwa skor rasa tertinggi dihasilkan pada roti berbahan pati ganyong HMT-GX yang berbeda tidak nyata dengan roti berbahan terigu dan

Tabel 6. Hasil uji hedonik roti yang dibuat dari pati ganyong

\begin{tabular}{lllll}
\hline \multirow{2}{*}{ Jenis Bahan } & \multicolumn{4}{c}{ Skor } \\
\cline { 2 - 5 } & Rasa & Warna & Tekstur & Aroma \\
\hline Pati ganyong HMT-GX & $5,34 \pm 0,87^{\mathrm{c}}$ & $5,46 \pm 0,54^{\mathrm{e}}$ & $5,56 \pm 0,64^{\mathrm{e}}$ & $5,80 \pm 0,61^{\mathrm{d}}$ \\
Pati ganyong HMT & $2,90 \pm 1,02^{\mathrm{a}}$ & $3,24 \pm 1,02^{\mathrm{b}}$ & $2,82 \pm 0,69^{\mathrm{b}}$ & $4,78 \pm 0,68^{\mathrm{b}} \mathrm{c}$ \\
Pati ganyong-GX & $5,00 \pm 0,83^{\mathrm{c}}$ & $3,66 \pm 0,75^{\mathrm{c}}$ & $3,60 \pm 0,93^{\mathrm{c}}$ & $4,52 \pm 0,95^{\mathrm{b}}$ \\
Pati ganyong & $3,62 \pm 1,32^{\mathrm{b}}$ & $2,88 \pm 0,82^{\mathrm{a}}$ & $3,16 \pm 1,09^{\mathrm{b}}$ & $3,86 \pm 0,88^{\mathrm{a}}$ \\
Pati jagung & $2,84 \pm 1,20^{\mathrm{a}}$ & $6,30 \pm 0.74^{\mathrm{f}}$ & $2,30 \pm 0,81^{\mathrm{a}}$ & $3,78 \pm 1,47^{\mathrm{a}}$ \\
Tepung terigu & $4,92 \pm 0,94^{\mathrm{c}}$ & $5,36 \pm 0,83^{\mathrm{d}}$ & $5,10 \pm 0,65^{\mathrm{d}}$ & $4,92 \pm 0,94^{\mathrm{c}}$ \\
\hline
\end{tabular}


pati ganyong yang ditambah GX, tetapi berbeda nyata dengan roti yang dibuat dari pati ganyong, pati jagung dan pati ganyong HMT. Sementara, untuk tingkat kesukaan tekstur dan aroma, kesukaan tertinggi juga terdapat pada roti pati ganyong HMT-GX yang berbeda nyata dengan roti yang dibuat dengan bahan yang lain. Uji hedonik terhadap parameter warna menunjukkan penilaian panelis tertinggi terdapat pada roti pati jagung yang berbeda nyata dengan roti yang dibuat dari bahan lain. Hasil uji mutu hedonik terhadap roti ganyong dapat dilihat pada Tabel 7.

Skor rasa, warna, dan tekstur roti berturut-turut berkisar antara 1,92 sampai 2,38 (enak); 1,00 sampai 2,46 (kuning sampai kuning kecoklatan); dan 1,62 sampai 2,82 (renyah sampai keras). Pati ganyong HMTGX mempunyai rasa paling enak dibandingkan bahan yang lain, warna kuning kecoklatan dan tekstur renyah. Hal ini disebabkan oleh modifikasi pati ganyong HMT-GX dapat mengubah sifat fisik pati dengan meningkatnya indeks absorbsi air (IAA) dan swelling power pati ganyong sehingga dapat menghasilkan produk rerotian bebas gluten yang mengembang (Parwiyanti, 2016). Berdasarkan hasil uji hedonik dan mutu hedonik dapat disimpulkan bahwa pati ganyong HMT-GX dapat digunakan sebagai bahan baku untuk produk roti karena disukai konsumen, enak, warna kuning kecoklatan dan tekstur renyah. Penentuan perlakuan terbaik berdasarkan uji hedonik, mutu hedonik dan sifat fisik roti yang dihasilkan. Roti yang dibuat menggunakan pati ganyong termodifikasi HMT-GX menghasilkan rasa, warna, tekstur, dan aroma yang paling disukai dengan mutu hedonik rasa paling enak, warna kuning kecoklatan dan tekstur renyah, berdasarkan gambar penampang melintang dan membujur roti, pori-pori roti yang dihasilkan dari pati ganyong termodifikasi HMTGX sudah menyerupai roti yang dibuat dari tepung terigu, nilai rasio tinggi dan diameter roti tertinggi $(0,75)$, mempunyai tekstur yang rapuh (keras tetapi mudah pecah), nilai $L^{*}$ roti 75,13 , dengan nilai $a^{*}$ dan $b^{*}$ berturut-turut $+9,37$ dan $+29,40$ (warna merah kuningan).

\section{KESIMPULAN}

Perlakuan jenis pati pada formulasi adonan roti berpengaruh nyata terhadap volume spesifik roti, nilai warna, tekstur, rasio tinggi dan diameter roti dan perbedaan kesukaan konsumen. Jenis pati terbaik sebagai bahan dasar roti berdasarkan sifat fisik, hedomik dan mutu hedonik adalah pati ganyong termodifikasi HMT-GX yang menghasilkan roti dengan karakteristik volume spesifik $2,85 \pm 0,017 \mathrm{~cm}^{3} \mathrm{~g}^{-1}$, warna $\left(L^{*}, a^{*}, b^{*}\right.$ berturut-turut 75,$\left.13 ;+9,37 ;+29,40\right)$, tekstur $109,03 \pm 7,50 \mathrm{~g}_{\mathrm{f}}$ rasio tinggi/diameter roti 0,74 , skor hedonik untuk rasa, warna, tekstur dan aroma berturutturut 5,$34 ; 5,46 ; 5,56$, dan 5,80 (5 = sedikit suka; $6=$ suka).

\section{DAFTAR PUSTAKA}

Al-Dmoor, H.M. and Galali, Y. (2014). Noverty formulas of free gluten flat bread for coeliac disearse patients. World Journal of medical Sciences 11(3):306-311. DOI: 10.5829/idosi.wjms.2014.11.3.84264

Alvarenga, N.B., Lidon, F.C., Belga, E., Motrena, P., Guerreiro, S., Carvalho, M.J., dan Canada, J. 2011. Characterization of gluten-free bread prepared from maize, rice and tapioca flours using the hydrocolloid seaweed agar-agar. Recent Research in Science and Technology. 3(8): 6468. www.scholarjournals.org.

Gambus, H., Sikora, M., dan Ziobro, R. (2007). The effect of composition of hydrocolloids on properties of gluten-free Bread. Acta Scientiarum Polonorum Technology Aliment 6(3):61-74.

Tabel 7. Skor mutu hedonik roti yang dibuat dari pati ganyong

\begin{tabular}{llll}
\hline \multicolumn{1}{c}{ Jenis Bahan } & \multicolumn{3}{c}{ Skor } \\
\cline { 2 - 4 } & Rasa & Warna & Tekstur \\
\hline Pati ganyong HMT-GX & $1,92 \pm 0,27^{\mathrm{a}}$ & $2,10 \pm 0,30^{\mathrm{c}}$ & $1,86 \pm 0,35^{\mathrm{b}}$ \\
Terigu & $2,10 \pm 0,58^{\mathrm{b}}$ & $1,50 \pm 0,51^{\mathrm{b}}$ & $2,44 \pm 0,66^{\mathrm{c}}$ \\
Pati ganyong-GX & $2,26 \pm 0,56^{\mathrm{b}} \mathrm{c}$ & $2,14 \pm 0,35^{\mathrm{c}}$ & $2,00 \pm 0,40^{\mathrm{b}}$ \\
Pati ganyong HMT & $2,36 \pm 0,48^{\mathrm{c}}$ & $2,46 \pm 0,50^{\mathrm{d}}$ & $1,56 \pm 0,53^{\mathrm{a}}$ \\
Pati jagung & $2,38 \pm 0,57^{\mathrm{c}}$ & $1,00 \pm 0,00^{\mathrm{a}}$ & $2,82 \pm 0,60^{\mathrm{d}}$ \\
Pati ganyong & $2,38 \pm 0,57^{\mathrm{c}}$ & $2,40 \pm 0,49^{\mathrm{d}}$ & $1,62 \pm 0,49^{\mathrm{a}}$ \\
\hline
\end{tabular}

Keterangan: Skor 1 sampai dengan 5 dengan kriteria untuk rasa (sangat enak sampai sangat tidak enak), warna (kuning sampai coklat), tekstur (renyah sampai keras) 
Gomashe, A.V., Dharmanik, P.G., dan Fuke, P.S. (2013). Optimization and production of xanthan gum by Xanthomonas campestris NRRL-B-1446 from suger beet molasses. The IJES 2(5): 52-55.

Hager, A., dan Arendt, E.K. (2013). Influence of hydroxypropylmethylcellulose (HPMC), xanthan gum and their combination on loaf specific volume, crumb hardness and crumb grain characteristics of gluten free breads based on rice, maize, teff and buckwheat. Food Hydrocoll. 32:195-203. http://dx.doi.org/10.1016/j. foodhyd.2012.12.021

Harmayani, E., Murdiati, A., dan Griyaningsih. (2011). Karakteristik pati ganyong (Canna edulis) dan pemanfaatannya sebagai bahan pembuatan cookies dan cendol. AGRITECH 31(4):297-303.

Kohajdova, Z., dan Karovicova, J. (2008). Influence of hydrocolloids on quality of baked goods. Acta Scientiarum Polonorum Technology Aliment 7(2):43-49.

Onyango, C., Mewa, E.A., Mutahi, A.W., dan Okoth, M.W. (2013). Effect of heat-moisture-treated cassava starch and amaranth malt on the quality of sorghum-cassavaamaranth bread. AFR. Journal of Food Science. 7(5):8086. http:// www.academicjournals.org/AJFS. DOI: 10.5897/AJFS2012.0612

Palaniraj, A. dan Jayaraman, V. (2011). Production, recovery and appications of xanthan gum by Xanthomonas campestris. Journal of Food Engineering. 106:1-12. DOI: 10.1016/j.jfoodeng.2011.03.035

Parwiyanti, Pratama, F., Wijaya, A., Malahayati, N., dan Lidiasari, E. (2015). Swelling power dan kelarutan pati ganyong (Canna edulis Kerr.) termodifikasi melalui heatmoisture treatment dan penambahan gum xanthan untuk produk roti. Prosiding Seminar Hasil Penelitian Tanaman Aneka Kacang dan Umbi. Malang tgl 19 Mei 2015. Hal: 692-699.

Parwiyanti, Pratama, F., Wijaya, A., Malahayati, N., Lidiasari, E. (2016). Sifat fisik pati ganyong (Canna edulis Kerr.) termodifikasi dan penambahan gum xanthan untuk rerotian. Agritech 36(3):335-347. http://dx.doi. org/10.22146/agritech.16606,ISSN: 0216-0455

Peressini, D., Pin, M.; dan Sensidoni, A. (2011). Rheology and breadmaking performance of rice-buckwheat batters supplemented with hydrocolloids. Food Hydrocolloids. 25:340-349. DOI: 10.1016/j.foodhyd.2010.06.012
Putri, W.D.R., Zubaidah, E., dan Ningtyas, D.W. (2014). Effect of heat moisture treatment on functional properties and microstructural profiles of sweet potato flour. Advance Journal of Food Science and Technology 6(5): 655-659.

Rakkar, P.S. (2007). Development of a gluten-free commercial bread. Thesis. Auckland University of Technology. Auckland

Slamet, A. 2010. Pengaruh perlakuan pendahuluan pada pembuatan tepung ganyong (Canna edulis) terhadap sifat fisik dan amilografi tepung yang dihasilkan. Agrointek 4(2):100-104.

Syamsir, E., Hariyadi, P., Fardiaz, D., Andarwulan, N., dan Kusnandar, F. 2012. Pengaruh proses heat-moisture treatment (HMT) terhadap karakteristik fisikokimia pati. J. Teknol dan Industri Pangan 23(1): 100-106.

Turabi, F., Sumnu, G., dan Sahin, S. (2010). Quantitative analysis of macro and micro-structure of gluten-free rice cakes containing different types of gums baked in different ovens. Food Hydrocoll. 24: 755-762. DOI: 10.1016/j.foodhyd.2010.04.001.

Utomo, J.S., Yulifianti, R., Kasno, A. (2012). Kajian sifat fisikokimia dan amilografi pati garut dan ganyong. Seminar hasil penelitian aneka kacang dan umbi. Malang. 673-680.

Vamadevan, V dan Bertoft, E. 2014. Structure-function relationships of starch components. Starch 66:1-14. DOI: 10.1002/Star.201400188.

Watcharatewinkul, Y., Puttanlek, C., Rungsardthong, V., dan Uttapap, D. (2009). Pasting properties of heatmoisture treated canna starch in relation to its structural characteristics. Carbohyd. Polym. 75(3):505-511. DOI: 10.1016/j.carbpol.2008.08.018.

Weber, F.H., Clerici, M.T.P.S., Collares-Queiroz, F.P., dan Chang, Y.K., (2009). Interaction of guar and xanthan gums with starch in the gels obtained from normal, waxy and highamylose corn starches. Starch 61:28-34. DOI: 10.1002/ star.200700655.

Widjajaputra, B. (2007). Pengelolaan tanaman terpadu untuk umbi-umbian. Sanggar anak bumi tani, Perkumpulan GEMPA, Yayasan KEHATI. Jogjakarta. 